\title{
Dating detrital zircon from the gold-bearing Ventersdorp Contact Reef in the Ventersdorp Supergroup of South Africa
}

\author{
D.H. Cornell ${ }^{\text {a,b, }}$, P.G. Meintjes ${ }^{c}$, W.A. Van der Westhuizen ${ }^{c}$, M. Kristoffersen ${ }^{\text {d }}$, D. Frei ${ }^{\text {e }}$ \\ ${ }^{\text {a }}$ Department of Earth Sciences, University of Gothenburg, Sweden \\ ${ }^{\mathrm{b}}$ Department of Earth Sciences, Stellenbosch University, Private Bag X1, 7602 Matieland, South Africa \\ ${ }^{\mathrm{c}}$ Department of Geology, University of the Free State, South Africa \\ ${ }^{\mathrm{d}}$ Department of Geosciences, University of Oslo, N-0316 Oslo, Norway \\ e Department of Geology, University of the Western Cape, Robert Sobukwe Rd, Bellville, Cape Town 7535, South Africa
}

\section{A R T I C L E I N F O}

\section{Keywords:}

Witwatersrand gold deposit

Ventersdorp contact reef

Detrital zircon dating

Lead loss

Th-induced radiation damage

\begin{abstract}
A B S T R A C T
The Ventersdorp Contact Reef (VCR) at the base of the $>4.5 \mathrm{~km}$-thick volcanosedimentary Ventersdorp Supergroup unconformably overlies the Witwatersrand Supergroup and is the second youngest mineable reef in the Witwatersrand Goldfields. The volcanic rocks of the Ventersdorp Supergroup are predominantly mafic, affected by low-grade thermal metamorphism and difficult to date. Only the Makwassie Formation in the upper Platberg Group of the main Ventersdorp repository has been reliably dated on four felsic volcanic samples at $2720 \pm 2 \mathrm{Ma}$. The actual timing of Ventersdorp volcanism and the duration of the three recognised lithostratigraphic groups remains enigmatic, despite much research and heroic attempts to synthesize the available data.

In this work detrital zircon grains from VCR conglomerates were $\mathrm{U}-\mathrm{Pb}$ dated in order to improve the time constraints on the Klipriviersberg Group at the base of the Ventersdorp Supergroup. The six youngest grains in VCR samples were reliably dated at $2799 \pm 9$ Ma. The Klipriviersberg Group and the Ventersdorp Supergroup is thus younger than $2808 \mathrm{Ma}$ and the supergroup is older than the $2642 \mathrm{Ma}$ Vryburg Formation at the base of the Transvaal Supergroup.

Comparisons of detrital grain dates confirm that the VCR was largely derived from erosion products of the underlying Witwatersrand Supergroup, however the youngest VCR grains are $\sim 20$ Ma younger and may have been derived directly from magmatic rocks in the provenance or a felsic facet of the synchronous komatiitic Klipriviersberg volcanism.

Multi-grain analyses of discordant grains show that recent lead loss is predominant. However about $5 \%$ of the data show the effect of complex Mesoproterozoic lead loss, which can yield ages as much as 150 Ma too young in $10 \%$ discordant data. This was found in grains with high Th-induced radiation damage, providing a criterion for data rejection.

The proposed large igneous provinces dated between 2791 and $2683 \mathrm{Ma}$, based mainly on dated mafic dykes, which are not in contact with supracrustal Ventersdorp rocks, do fit the established time constraints and might provide a key to Ventersdorp chronostratigraphy. However only the proposed 2754-2709 Ma Platberg volcanic province is based on reliably dated Platberg Group volcanic rocks.
\end{abstract}

\section{Introduction}

The Archean Ventersdorp Supergroup is a major volcanic and sedimentary sequence with recorded thickness of at least $4.5 \mathrm{~km}$, which overlies the gold-bearing Witwatersrand Supergroup in South Africa. It is probably the most-drilled sequence in the world due to exploration for deep-lying Witwatersrand gold reefs over the past 150 years (Figs. 1 and 2).

Direct dating of the volcanic units in the Ventersdorp Supergroup is hampered by their generally mafic to komatiitic compositions which were undersaturated in zircon, so that zircon grains extracted from them are likely to be dominated by older xenocrysts. Only the intermediate to

\footnotetext{
* Corresponding author.

E-mail addresses: david.cornell@cantab.net (D.H. Cornell), pgm@pgmmanagement.co.za (P.G. Meintjes), magnus.kristoffersen@geo.uio.no (M. Kristoffersen), dfrei@uwc.ac.za (D. Frei).
} 


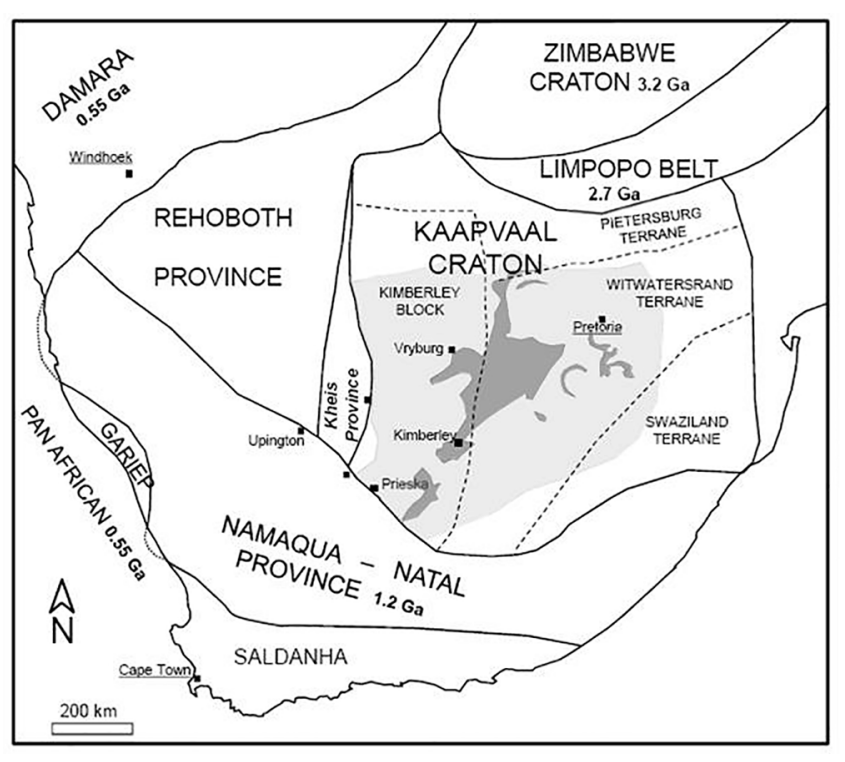

Fig. 1. Precambrian structural provinces of southern Africa and terranes of the Kaapvaal Craton, showing the outcrop area of the Archaean Ventersdorp Supergroup (dark shading) and the inferred suboutcrop area (light shading), after Cornell et al. (2017).

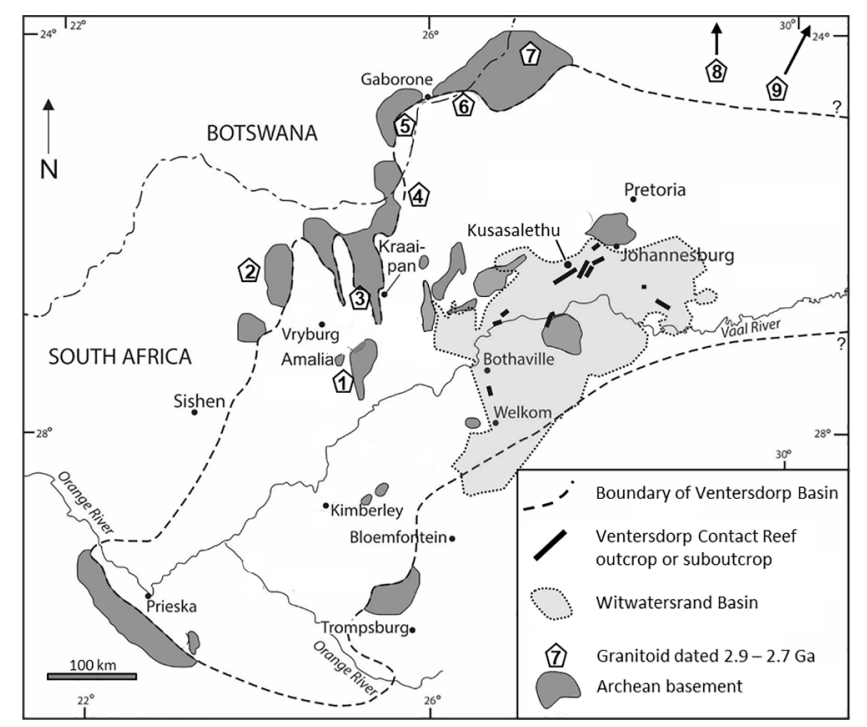

Fig. 2. The extent of the preserved (outcrop and suboutcrop) basins of the Witwatersrand and Ventersdorp supergroups on the Kaapvaal Craton of South Africa after McCarthy (1994) and Van der Westhuizen et al. (2006) respectively. The known occurrences of the Ventersdorp Contact Reef (VCR) are shown after McCarthy (1994) and the locality of Kusasalethu Mine is shown, from which the samples were taken. The numbered localities are granitoids dated between 2.9 and $2.7 \mathrm{Ga}$ in the possible provenance area of the VCR, detailed in supplementary Table A1.

felsic lavas from the Makwassie and Goedgenoeg formations in the Platberg Group, which forms the middle to upper part of the Ventersdorp Supergroup, have yielded abundant magmatic zircon grains. Added to that is a regional greenschist facies thermal metamorphic imprint, which corresponds broadly in age to the $2.06 \mathrm{Ga}$ Bushveld Complex. This event recrystallised igneous minerals and affected many isotopic systems in the Kaapvaal Craton (Cornell, 1978; Schweitzer and Kröner, 1985; Armstrong, 1987). Conventional U-Pb zircon dating gave ages between 2.64 and $2.24 \mathrm{Ga}$ for the Makwassie Formation. The ion probe investigation of Armstrong et al. (1991) was for the first time able to target unaltered zircon age domains and revised the age to $2709 \pm 4$ Ma (reviewed by van der Westhuizen et al., 2006).

In a recent paper we established a precise U-Pb zircon date of $2720 \pm$ 2 Ma for four rhyolite samples from the Makwassie Formation in the Platberg Group (Cornell et al., 2017). Gumsley et al. (2020) reported U$\mathrm{Pb}$ baddeleyite ages for three mafic sills and a dyke which were emplaced by intrusion into the Witwatersrand and Pongola supergroups (Table 1). They correlated them with the Klipriviersberg and Platberg groups and postulated the existence of three mafic large igneous provinces (LIPs) and a felsic volcanic province, based on these data and a review of published precise ages of many intrusive and a few extrusive rocks. These are the 2791-2779 Ma Klipriviersberg LIP, the 2754-2709 Platberg Volcanic Province, 2709-2683 Ma Allanridge LIP and the 2664-2654 Ma White Mfolozi LIP.

This work reports $\mathrm{U}-\mathrm{Pb}$ data for detrital zircon from the gold-bearing Ventersdorp Contact Reef (VCR), which lies at the base of the Ventersdorp Supergroup (Fig. 3), in an effort to better constrain the age of the supergroup and to interpret the source of sedimentary material. The VCR is a conglomerate which unconformably overlies the previously lithified and variably eroded Witwatersrand Supergroup, from which much of the gold was derived. The VCR conglomerates form part of the Venterspost Formation (Fig. 3), which includes interbedded komatiitic lavas, minor sandstones and shales. There has been debate about whether the VCR should be placed at the top of the Witwatersrand Supergroup or in the Klipriviersberg Group at the base of the Ventersdorp (reviewed by van der Westhuizen et al. 2006). The latter alternative is supported by the major angular and erosional unconformity beneath the VCR, as well as its intercalation in places and soft-sediment deformation by komatiitic basalts of the overlying Westonaria Formation (Hall et al., 1997).

The mineralogy of the VCR at the Kusasalethu (then named Elandsrand) Mine, from which our samples were collected, was described by Henckel and Schweizer (1994). The VCR consists mainly of quartz or quartz-chlorite pebbles, with a matrix consisting of quartz and chlorite, with variable amounts of pyrrhotite, chalcopyrite, galena. sphalerite, zircon, carbon, chromite and gold. They regarded the mineral assemblage to reflect major recrystallisation by hydrothermal processes, evidenced by the complete replacement of original clastic pyrite grains by pyrrhotite and chlorite, together with the occurrence of authigenic tourmaline and molybdenite. Zhao et al (1999) confirmed most of these minerals in samples from the adjoining Western Deep Levels mine by Xray diffraction and also documented major amounts of muscovite, minor albite pyrite and rutile and trace epidote and calcite. They recognised four paragenetic stages of alteration starting with pyrite-pyrrhotitesphalerite assemblages and ending with quartz-calcite veining. They obtained K-Ar isochron ages between 1994 and $1917 \mathrm{Ma}$, which they ascribed to resetting by $350-290{ }^{\circ} \mathrm{C}$ hydrothermal alteration, broadly coeval with the intrusion of the $\sim 2054$ Ma Bushveld Complex and the $\sim 2020$ Ma Vredefort impact event.

Ion probe data for 20 detrital zircon grains from the VCR were reported by Barton et al. (1989). The age of the youngest grain (5.1) was cited by Gumsley et al. (2020) as $2780 \pm 5 \mathrm{Ma}$, but that age is actually $2776 \pm 102 \mathrm{Ma}(2 \sigma)$ and the point is $65 \%$ discordant. The youngest concordant grain (6.1) has an ${ }^{207} \mathrm{~Pb} /{ }^{206} \mathrm{~Pb}$ age of $2842 \pm 80 \mathrm{Ma}(2 \sigma)$ and our re-evalution of the data gives $2785 \pm 56 \mathrm{Ma}$ (Table 1). This unit needs revisiting, as it can provide a useful age constraint on the lowermost Ventersdorp strata as well as its provenance.

\section{Sample descriptions}

Ventersdorp Contact Reef (VCR) conglomerate samples from the different reef types Kusasalethu Mine were kindly supplied by $\mathrm{Mr}$ Johann Ackermann of Harmony Gold Mining Co. Ltd. They were arbitrarily labelled A to D. The samples comprise mainly pale to dark quartz pebbles in a matrix dominated by quartz, and pyrite or pyrrhotite, as shown in supplementary Fig. A2.1. For zircon separation, sample D and 
Table 1

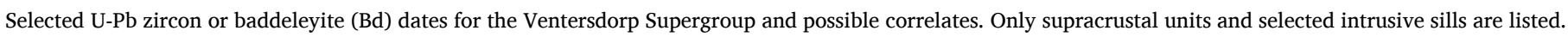

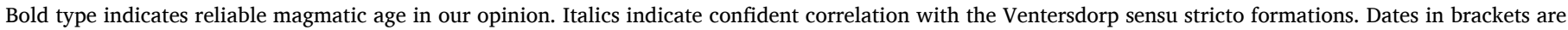

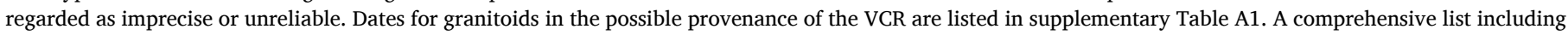
intrusive rocks and rocks from outside the Ventersdorp repository can be found in Gumsley et al. (2020).

\begin{tabular}{|c|c|c|c|c|c|c|}
\hline No. & Unit Dated & $\begin{array}{l}\text { Age } \\
\mathrm{Ma}\end{array}$ & $\begin{array}{l} \pm 2 \sigma \\
\mathrm{Ma}\end{array}$ & Method & Comments & Reference \\
\hline 1 & Lower Makwassie Formation & $(2709)$ & 4 & Ion probe ${ }^{207} \mathrm{~Pb} /{ }^{206} \mathrm{~Pb}$ & $\begin{array}{l}\text { First hope for reliably dating the Ventersdorp, } \\
\text { but high common lead and inconsistent with } \\
\text { nos. } 5,6,7\end{array}$ & Armstrong et al. (1991) \\
\hline 2 & Klipriviersberg Group & $(2714)$ & 16 & Ion probe ${ }^{207} \mathrm{~Pb} /{ }^{206} \mathrm{~Pb}$ & Minimum age, probable ancient lead loss & Armstrong et al. (1991) \\
\hline 3 & $\begin{array}{l}\text { Kareefontein Fm., Zoetlief Gp. } \\
\text { LNV014 Vryburg Area }\end{array}$ & 2718 & 6 & Laser Ablation ICPMS & Age of extrusion Makwassie Fm. correlate & Cornell et al. (2017) \\
\hline 4 & $\begin{array}{l}\text { Seekoebaard Formation } \\
\text { conglomerate near Marydale }\end{array}$ & 2720 & 4 & Laser Ablation ICPMS & $\begin{array}{l}\text { Single detrital zircon population dates } \\
\text { volcanism, overlain by andesites which } \\
\text { correspond geochemically to Allanridge } \\
\text { Fm. }\end{array}$ & Cornell et al. (2018) \\
\hline 5 & $\begin{array}{l}\text { Upper Makwassie Formation } \\
\text { FVM905, type area near } \\
\text { Wolmaransstad }\end{array}$ & 2722 & 6 & Laser Ablation ICPMS & Age of extrusion & Cornell et al. (2017) \\
\hline 6 & $\begin{array}{l}\text { Lower Makwassie Formation } \\
\text { FVM205_LLE Wolmaransstad } \\
\text { Area }\end{array}$ & 2721 & 6 & Laser Ablation ICPMS & Age of extrusion & Cornell et al. (2017) \\
\hline 7 & $\begin{array}{l}\text { Upper Makwassie Formation } \\
\text { VLF258, Vryburg Area }\end{array}$ & 2723 & 6 & Laser Ablation ICPMS & Age of extrusion & Cornell et al. (2017) \\
\hline 8 & Phokwane Formation & 2724 & 6 & Ion probe ${ }^{207} \mathrm{~Pb} /{ }^{206} \mathrm{~Pb}$ & Correlate of Makwassie Fm. Platberg Gp. & De Kock et al. 2012 \\
\hline 9 & $\begin{array}{l}\text { Mafic sill in Witwatersrand } \\
\text { Supergroup (PRGE) }\end{array}$ & 2727 & 3 & U-Pb TIMS Bd & $\begin{array}{l}\text { Time correlate of Platberg Gp. but no field } \\
\text { relations }\end{array}$ & Gumsley et al. (2020) \\
\hline 10 & $\begin{array}{l}\text { Paardefontein Formation near } \\
\text { Amalia }\end{array}$ & 2729 & 3 & Ion probe discordia & $\begin{array}{l}\text { Overlies Amalia Greenstone Belt, correlate of } \\
\text { Makwassie Fm. }\end{array}$ & Poujol et al. (2005) \\
\hline 11 & Mohle Formation, Taung Area & 2733 & 8 & Ion probe discordia & Correlate of Kameeldoorns Fm. Platberg Gp. & De Kock et al. (2012) \\
\hline 12 & $\begin{array}{l}\text { Ongers River Formation, Sodium } \\
\text { Group }\end{array}$ & 2739 & (39) & Ion probe ${ }^{207} \mathrm{~Pb} /{ }^{206} \mathrm{~Pb}$ & $\begin{array}{l}\text { Duplicated with precision <10 Ma. Correlate } \\
\text { of lower Platberg Group }\end{array}$ & $\begin{array}{l}\text { Altermann and Lenhardt (2012), } \\
\text { Altermann personal } \\
\text { communication with DHC }\end{array}$ \\
\hline 13 & $\begin{array}{l}\text { Lower Goedgenoeg Formation } \\
\text { FVM207_LLE Wolmaransstad Area }\end{array}$ & $(2746)$ & 9 & Laser Ablation ICPMS & $\begin{array}{l}\text { Probably xenocryst age, confirmed by new data } \\
\text { in press. }\end{array}$ & Cornell et al. (2017) \\
\hline 14 & Derdepoort outlier E of Gaborone & $(2769)$ & 2 & $\begin{array}{l}\text { Kober method } \\
{ }^{207} \mathrm{~Pb} /{ }^{206} \mathrm{~Pb}\end{array}$ & $\begin{array}{l}\text { Possible Klipriviersberg Gp., Ventersdorp } \\
\text { Supergroup correlate }\end{array}$ & Walraven et al. (1996) \\
\hline 15 & $\begin{array}{l}\text { Felsite acribed to Kanye Formation } \\
\text { in Derdepoort outlier E of Gaborone }\end{array}$ & $(2781)$ & 2 & Ion probe ${ }^{207} \mathrm{~Pb} /{ }^{206} \mathrm{~Pb}$ & Inferred age based on disputed field relations & Wingate (1998) \\
\hline 16 & $\begin{array}{l}\text { VCR Venterspost Fm. Youngest } \\
\text { detrital zircon }\end{array}$ & $(2785)$ & 56 & Ion probe ${ }^{207} \mathrm{~Pb} /{ }^{206} \mathrm{~Pb}$ & $\begin{array}{l}\text { Ventersdorp Contact Reef younger than this, } \\
\text { superceded by no. } 21\end{array}$ & $\begin{array}{l}\text { Barton et al. (1990) errors } \\
\text { assessed by DHC using the } \\
\text { original data. }\end{array}$ \\
\hline 17 & $\begin{array}{l}\text { Middle Goedgenoeg (?) } \\
\text { Formation LWS995, Wesselton } \\
\text { Mine, Kimberley }\end{array}$ & 2781 & 5 & Laser Ablation ICPMS & $\begin{array}{l}\text { Extrusion age, but not Goedgenoeg } \mathrm{Fm} . \\
\text { according to new data in press }\end{array}$ & Cornell et al. (2017) \\
\hline 18 & $\begin{array}{l}\text { Kanye Formation (Lobatse Group) } \\
\text { N. of Mafikeng, RSA }\end{array}$ & 2781 & 2 & $\begin{array}{l}\text { Kober method } \\
{ }^{207} \mathrm{~Pb} /{ }^{206} \mathrm{~Pb}\end{array}$ & $\begin{array}{l}\text { Possible early Ventersdorp correlate, same } \\
\text { samples as Moore et al. } 1993\end{array}$ & Grobler and Walraven (1993) \\
\hline 19 & $\begin{array}{l}\text { Kanye Formation N. of Mafikeng, } \\
\text { RSA }\end{array}$ & 2785 & 2 & $\begin{array}{l}\text { Krogh Method U- } \\
\text { PbTIMS }\end{array}$ & $\begin{array}{l}\text { Possible Ventersdorp correlate but outside } \\
\text { main repository }\end{array}$ & Moore et al. (1993) \\
\hline 20 & $\begin{array}{l}\text { Mafic sills in Witwatersrand } \\
\text { Supergroup (AM1 \& VJ1) }\end{array}$ & 2787 & 2 & U-Pb TIMS Bd & $\begin{array}{l}\text { Geochemically similar to Klipriviersberg } \\
\text { but no field relations }\end{array}$ & Gumsley et al. (2020) \\
\hline 21 & $\begin{array}{l}\text { VCR Venterspost Fm. Youngest } \\
\text { detrital zircons, multipoint data for } \\
6 \text { of } 86 \text { dated grains }\end{array}$ & 2799 & 8 & $\begin{array}{l}\text { Concordia age for } 17 \\
\text { points in } 6 \text { grains Laser } \\
\text { Ablation ICPMS }\end{array}$ & Supercedes no. 16 & This work \\
\hline 22 & $\begin{array}{l}\text { Lower Makwassie Formation } \\
\text { LWS013, Wesselton Mine } \\
\text { Kimberley }\end{array}$ & $(2874)$ & 16 & Laser Ablation ICPMS & $\begin{array}{l}\text { Interpreted as xenocryst age, one point gave } \\
2711 \pm 16 \mathrm{Ma}\end{array}$ & Cornell et al. (2017) \\
\hline
\end{tabular}

a combined $\mathrm{A}$ and $\mathrm{C}$ were processed.

\section{Methods.}

The samples were processed and mounted in epoxy pucks for U-Pb dating as described by Cornell et al. $(2016,2017)$ and the methods are documented in supplementary Table A3. Laser ablation multicollector ICPMS U-Pb analyses were done at the Department of Geosciences at Oslo University, Norway, as described by Andersen et al. (2009), with spot size of $40 \mu \mathrm{m}$. A second analytical run concentrating on the youngest grains was done by laser ablation quadrupole ICPMS at the University of Stellenbosch with spot size $25 \mu \mathrm{m}$, as described by Cornell et al. (2016). The data and radiation damage calculations are given in supplementary Table A6.

\section{Results}

Zircon grains were extracted and mounted from three conglomerate samples from the VCR. They are generally quite large grains (smallest 100x50, largest 400x400 microns) and most of them have a pink colour which does not seem to be correlated with age. Most grains were CL-dark as shown in Fig. 4 and only a few showed CL-brighter cores which could be older than the rims, e.g. grains 1 and 5 .

The data from the first campaign at the University of Oslo are shown on a concordia diagram in Fig. 5. The points with youngest ${ }^{207} \mathrm{~Pb} /{ }^{206} \mathrm{~Pb}$ ages are discordant, and in the ${ }^{207} \mathrm{~Pb} /{ }^{206} \mathrm{~Pb}$ age histograms there is a shift to younger ages in the more discordant data. This suggests that some or all of the discordant points may have experienced ancient lead loss, which would decrease the ${ }^{207} \mathrm{~Pb} /{ }^{206} \mathrm{~Pb}$ ages. This aspect was further investigated in a second dating campaign which aimed to accurately 


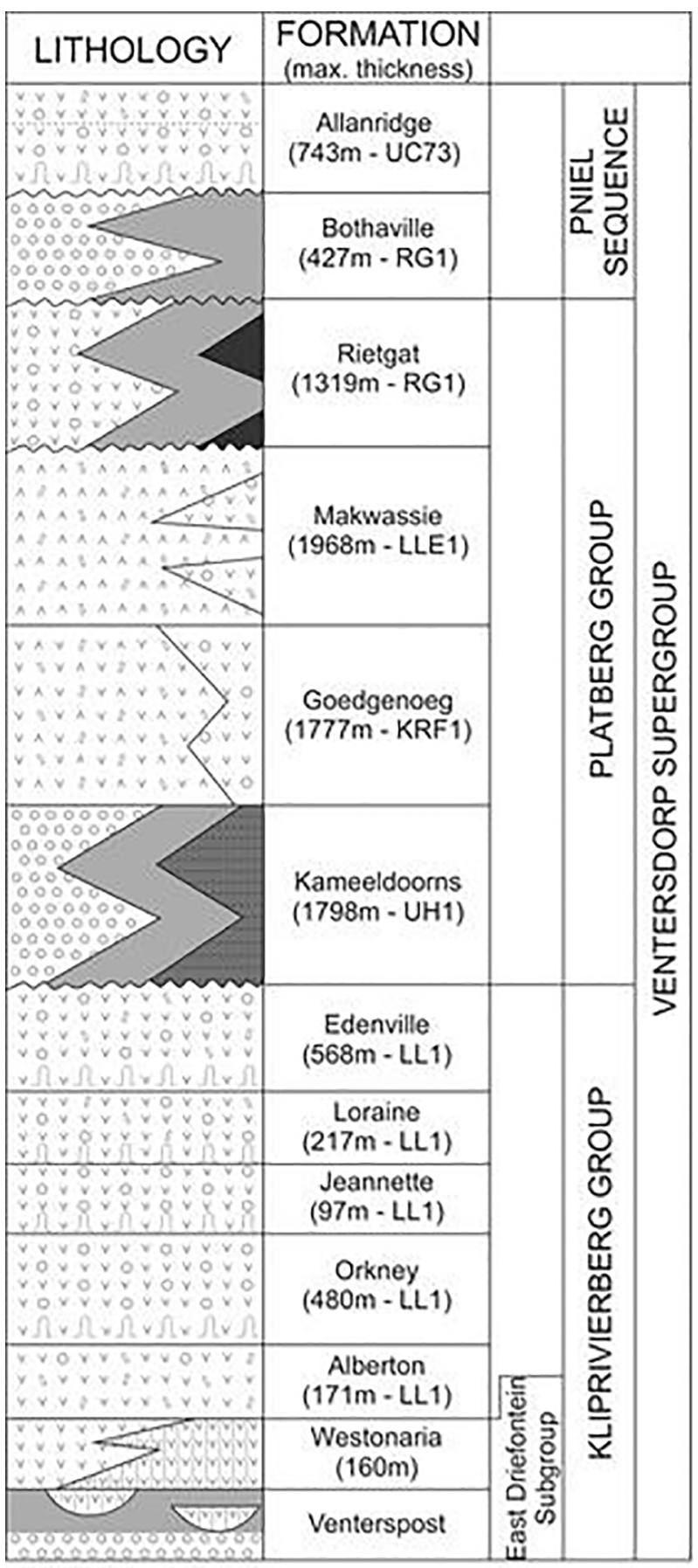

\begin{tabular}{|c|c|c|c|}
\hline 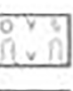 & $\begin{array}{l}\text { Mafic lava, tuff } \\
\text { (Jo amygdaloidal; } \\
\text { porphyritic) }\end{array}$ & & $\begin{array}{l}\text { Stromatolitic limestone, } \\
\text { chert }\end{array}$ \\
\hline $\begin{array}{lll} & A & y \\
v & s & v \\
\end{array}$ & $\begin{array}{l}\text { Intermodiate lava } \\
\text { ( i porphyritic) }\end{array}$ & & Shale, siltstone \\
\hline 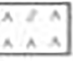 & $\begin{array}{l}\text { Folsic lava } \\
\text { ( porphyritic) }\end{array}$ & & Quartzite, greywacke \\
\hline 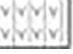 & Komatitic lava & 5000 & Conglomerate, breccia \\
\hline
\end{tabular}

Fig. 3. Stratigraphy of the Ventersdorp Supergroup after Van Der Westhuizen et al. (2006) and references therein. The VCR is shown as conglomerate at the base of the Venterspost Formation, which lies unconformably on the Witwatersrand Supergroup. The Ventersdorp Supergroup is unconformably overlain by the Transvaal Supergroup. define the age of the youngest grains. Eight grains, including six with the youngest ${ }^{207} \mathrm{~Pb} /{ }^{206} \mathrm{~Pb}$ ages, were dated at Stellenbosch University, analysing up to seven points in each grain. Fig. 6 and Table 2 shows the age calculations for each of these grains, for which the full data are given in supplementary Table A6.

\section{Discussion}

\subsection{Age of youngest detrital zircon grains.}

As shown in Table 2, the six youngest grains all yield concordia and discordia intercept ages close to $2800 \mathrm{Ma}$, the most precise being 2799 $\pm 14 \mathrm{Ma}$ for grain D84. The discordia intercepts for 27 of the 33 points including 17 concordant ones yield an acceptable recent lead loss discordia line with upper intercept $2799 \pm 11 \mathrm{Ma}$ and the concordant points yield $2799 \pm 9 \mathrm{Ma}$ (Fig. 6A). This is a precise estimate of the age of youngest detrital zircon grains in the Ventersdorp Contact Reef.

To conclude, a reliable age for the youngest detrital zircon grains in this study of the Ventersdorp Contact Reef is $2799 \pm 9$ Ma. The VCR and the Ventersdorp Supergroup is younger than that. This supercedes the age of $2895 \pm 22$ Ma based on three imprecise ion probe analyses, reported by Barton et al. (1990).

\subsection{Ancient lead loss in some domains}

The six points which show complex ancient lead loss all have Th concentrations more than $170 \mathrm{ppm}$ and $\mathrm{U}$ more than $350 \mathrm{ppm}$, whereas those conforming to recent lead loss have Th in the range 10-150 ppm and U 38-550, as shown in supplementary Fig. A2.2. Radiation dose calculations illustrated in supplementary Fig. A2.3 show that radiation damage due to Th provides a clear distinction between points which show recent lead loss $(n=10)$ or ancient lead loss $(n=6)$, whereas the total radiation dose due to $\mathrm{U}$ and $\mathrm{Th}$ is less definitive. Several grains yielded points with both types of discordance as well as concordant points $(\mathrm{n}=17)$.

Can the ancient lead loss be related to geological events? The imprecise lower intercept of $818 \pm 130 \mathrm{Ma}$, shown in Fig. 6, probably represents more than one event. Baughman and Flowers (2020) showed that the central Kaapvaal Craton had been at the surface about $1.4 \mathrm{Ga}$ and buried beneath $\geq 3.7 \mathrm{~km}$-thick sediment derived from mountains in the adjoining Namaqua-Natal Province after $1.2 \mathrm{Ga}$. This process and the subsequent denudation probably gave rise to complex lead loss in radiation-damaged zircon domains. Zircon dating of Ventersdorp Supergroup zircon grains has been plagued from the outset by lead loss and common lead problems. Our data shows that these can be resolved by well-controlled microbeam analysis and the acquisition of enough data.

\subsection{Source of VCR zircon grains}

Referring only to the $<10 \%$ discordant data in Fig. $6 \mathrm{~B}$ and $7 \mathrm{~A}$ and bearing in mind the histogram channel width of $20 \mathrm{Ma}$, there are major age groups at 3080-2960, 2940-2840 and $2800 \mathrm{Ma}$ and minor groups at $3360-3300,3200$, and $3120 \mathrm{Ma}$. The obvious source for most of the VCR conglomerate is the unconformably underlying Central Rand Group of the Witwatersrand Supergroup, for which Kositcin and Krapež (2004) published a detailed study of detrital zircon $\mathrm{U}-\mathrm{Pb}$ ages in eight samples from six formations, compiled data shown in Fig. 7B. Their data shows quite large differences in age histograms between and within formations, with varying similarity to that of the VCR. Their three samples from the Krugersdorp Formation, near the base of the Central Rand Group are a fairly good match for our VCR data (not shown). However, the three samples from Mondeor and Elsburg Formations near the top of the Central Rand Group do not correspond well, as two of them have a major peak at $3440 \mathrm{Ma}$, not seen in the VCR (not shown). The probability plot shown in Fig. 6B for the Eldorado Reef, uppermost mined reef in the Central Rand Group, using data from Koglin et al. (2010), also 


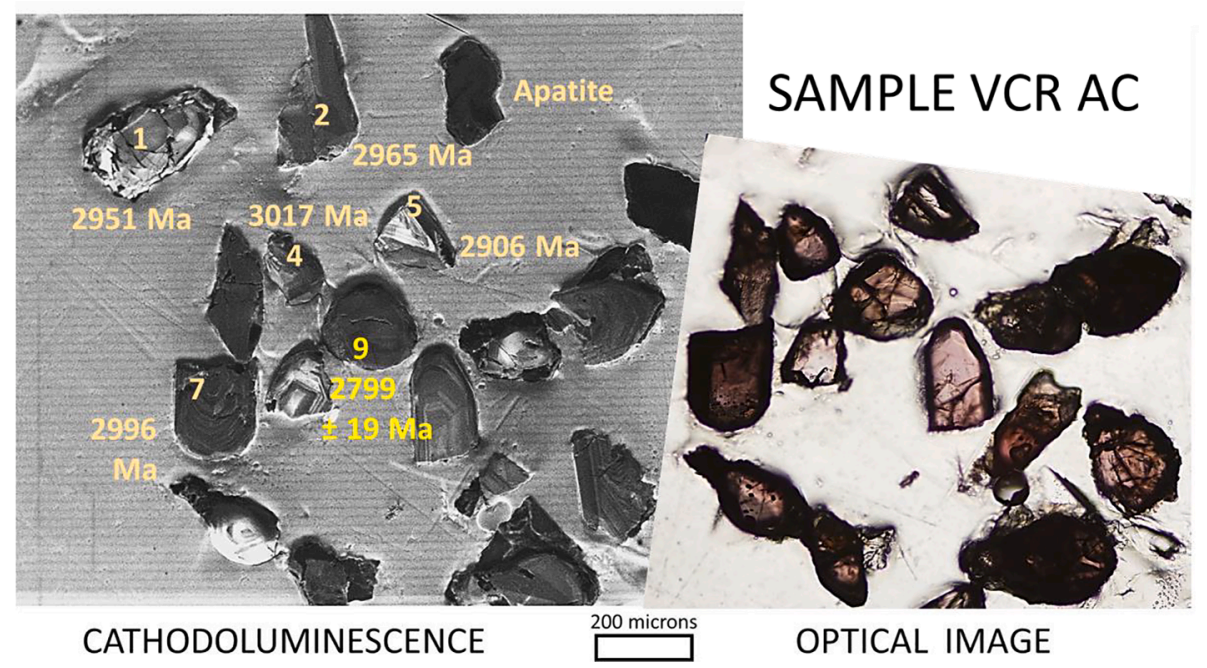

Fig. 4. Cathodoluminescent and optical images of zircon grains extracted from the Ventersdorp Contact Reef sample AC. Note the generally pink colour of the zircon grains, unrelated to age. ${ }^{207} \mathrm{~Pb} /{ }^{206} \mathrm{~Pb}$ ages are shown in tan font; shown in yellow is a multi-point concordia age.
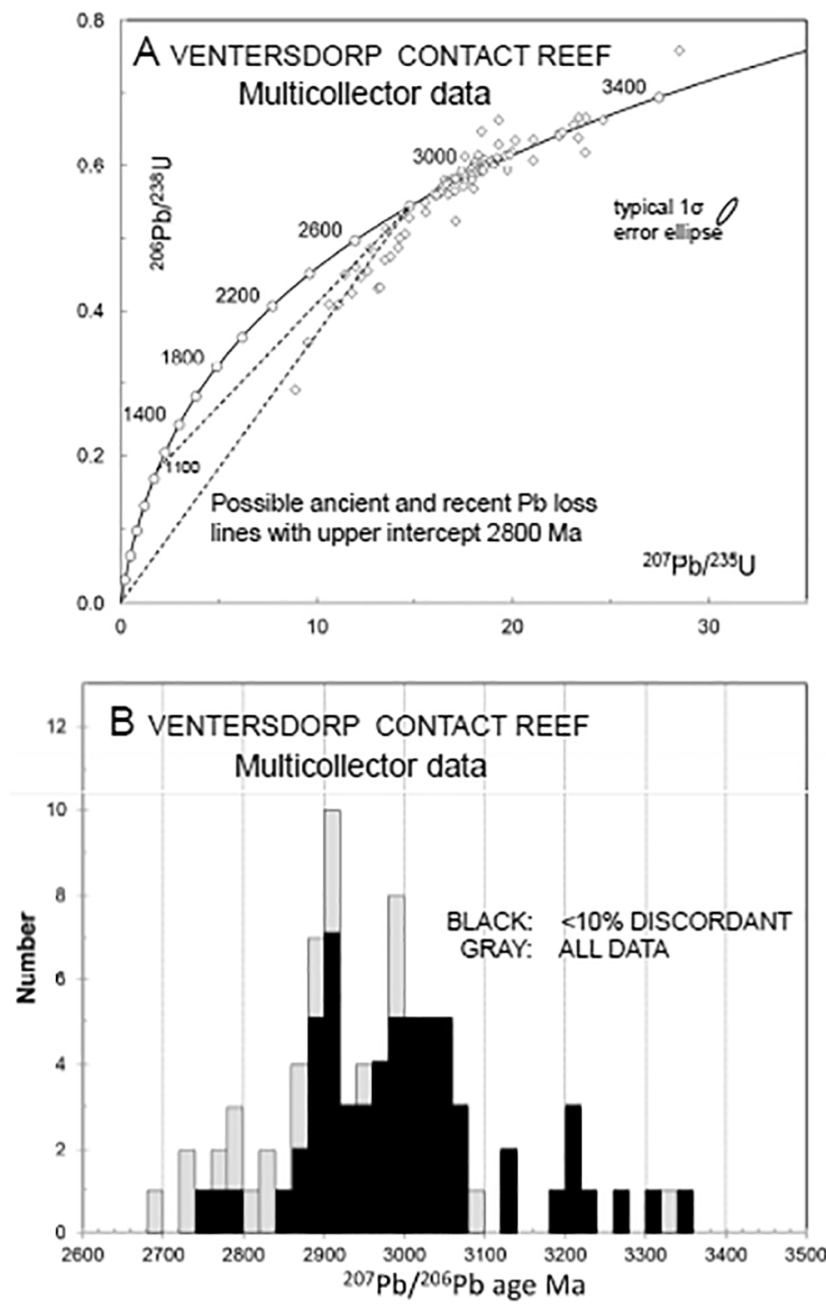

Fig. 5. Multicollector U-Pb data for detrital zircon grains from Ventersdorp Contact Reef samples AC and D. A: concordia diagram, B: histogram, showing ${ }^{207} \mathrm{~Pb} /{ }^{206} \mathrm{~Pb}$ ages for all data and data points with $<10 \%$ discordance.
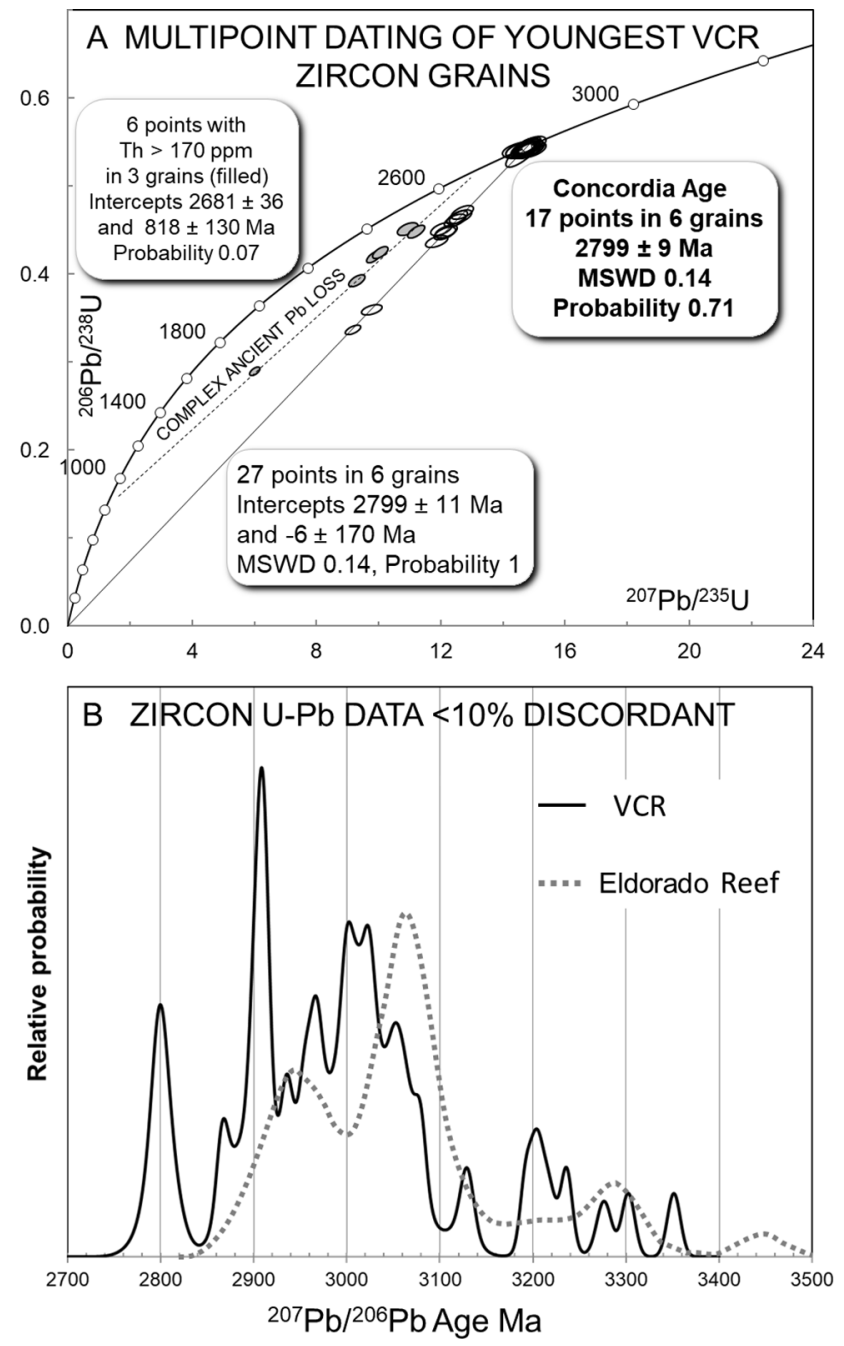

Fig. 6. A: Concordia diagram showing quadrupole multipoint data for the youngest zircon grains in the Ventersdorp Contact Reef samples AC and D. B: probability plot showing all the $<10 \%$ discordant data from both instruments, with duplicate grains removed. 
Table 2

Age calculations for the six youngest and two older grains analysed by LA-ICP quadrupole mass spectrometer.

\begin{tabular}{|c|c|c|c|c|c|c|c|c|c|c|c|c|}
\hline \multicolumn{2}{|c|}{ Youngest grains } & \multicolumn{6}{|c|}{ Discordia age calculations [Ma] } & \multicolumn{4}{|c|}{ Concordia calculations } & \multirow[b]{2}{*}{ Comments } \\
\hline Grain & $\begin{array}{l}\text { Points } \\
\text { analysed }\end{array}$ & Upper & $\pm 2 \sigma$ & Lower & $\pm 2 \sigma$ & Probability & No. & age & $\pm 2 \sigma$ & Probability & $\begin{array}{l}\text { no. } \\
\text { points }\end{array}$ & \\
\hline AC9 & 6 & 2806 & 29 & -7 & 220 & 0.98 & 6 & 2799 & 19 & 0.56 & 4 & 2 points show recent $\mathrm{Pb}$ loss \\
\hline AC15 & 5 & 2785 & 54 & 20 & 970 & 0.37 & 3 & 2788 & 37 & 0.8 & 1 & 2 points show recent, 2 show ancient $\mathrm{Pb}$ loss \\
\hline AC27 & 7 & 2804 & 35 & 83 & 540 & 0.99 & 7 & 2797 & 25 & 0.49 & 2 & $\begin{array}{l}\text { Recent } \mathrm{Pb} \text { loss, low } \mathrm{Th} / \mathrm{U} \text { suggests } \\
\text { metamorphic }\end{array}$ \\
\hline D4 & 5 & 2804 & 35 & 207 & 810 & 0.96 & 4 & 2802 & 24 & 0.86 & 3 & $\begin{array}{l}1 \text { point with } 343 \mathrm{ppm} \text { Th shows ancient } \mathrm{Pb} \\
\text { loss }\end{array}$ \\
\hline D82 & 4 & 2795 & 210 & 1256 & 740 & 0.04 & 4 & 2804 & 31 & 0.93 & 1 & 3 points scatter about ancient $\mathrm{Pb}$ loss line \\
\hline D84 & 6 & N/A & & & & & & 2799 & 14 & 0.83 & 6 & All concordant, precise age for one grain \\
\hline $\begin{array}{l}\text { Wtd. } \\
\text { Means }\end{array}$ & 6 & 2803 & 17 & & & 0.97 & 5 & 2798 & 9 & 0.99 & 6 & Weighted mean of above calculations \\
\hline $\begin{array}{l}\text { All } \\
\text { points }\end{array}$ & 33 & 2799 & 11 & -6 & 170 & 1 & 27 & 2799 & 9 & 0.71 & 17 & $\begin{array}{l}\text { Six points with } \mathrm{Th}>170 \mathrm{ppm} \text { scatter } \\
\text { about ancient } \mathrm{Pb} \text { loss line }\end{array}$ \\
\hline \multicolumn{13}{|c|}{ Grains interpreted as older } \\
\hline D80 & 6 & 3053 & 18 & 11 & 1400 & 0.9 & 6 & 3052 & 15 & 0.83 & 5 & Older grain, conforms to recent $\mathrm{Pb}$ Loss \\
\hline D182 & 4 & 2860 & 46 & 152 & 260 & 0.78 & 4 & 2804 & 45 & 0.43 & 1 & Two age domains in CL, core may be older. . \\
\hline
\end{tabular}
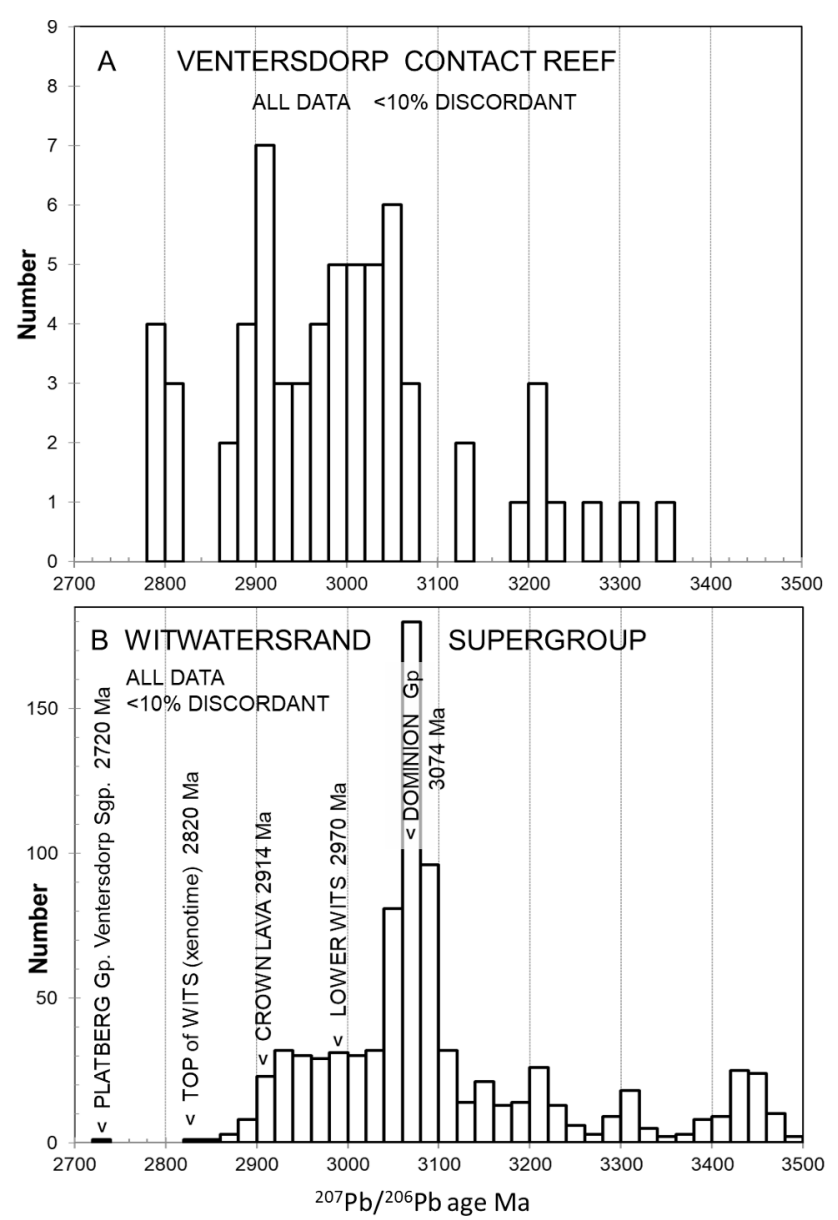

Fig. 7. Histograms of ${ }^{207} \mathrm{~Pb} /{ }^{206} \mathrm{~Pb}$ ages. A: detrital zircon grains in the Ventersdorp Contact Reef using only $<10 \%$ discordant data and excluding duplicate points, compared with B: all the data for the Witwatersrand Group from Kositicin and Krapež (2004), also showing the ages of other relevant units.

shows little similarity to that of the VCR. These differences can be explained by the major erosional unconformity beneath the VCR, which in places removed most of the $\sim 2.9 \mathrm{~km}$-thick Central Rand Group, wellillustrated by the seismic reflection data of Manzi et al. (2013). The VCR also represents the second youngest reef, (after the Black Reef in the Transvaal Supergroup) which is mined for gold, probably derived mainly from erosion of the underlying reefs, as reviewed by Chunnett
(1994).

Could all of the VCR zircon grains come from the WitwatersrandSupergroup? The Crown Lava in the middle of the Witwatersrand Supergroup is dated at $2914 \mathrm{Ma}$ (reviewed by Eglington and Armstrong, 2004). Weighted mean ${ }^{207} \mathrm{~Pb} /{ }^{206} \mathrm{~Pb}$ ages for the three youngest concordant detrital zircon grains from the Central Rand Group, Witwatersrand Supergroup, dated by Kositcin and Krapež (2004) are $2872 \pm 12 \mathrm{Ma}$ and for the three youngest detrital xenotime grains 2820 $\pm 5 \mathrm{Ma}$ (our calculations), possibly derived from non-zircon-bearing magmatic source rocks. According to Kositcin et al. (2003), diagenetic xenotime was growing in the Central Rand Group sedimentary rocks at $2778 \pm 2 \mathrm{Ma}$ (our calculation), so the Witwatersrand Supergroup is older than that. These dates suggest that the very youngest $2799 \pm 9 \mathrm{Ma}$ VCR zircon grains were not reworked from the Witwatersrand Supergroup, which was being eroded at that time. Five of the six youngest zircon grains are euhedral crystals, whereas most of the older grains are subhedral or broken. The youngest grains were possibly directly derived from plutonic magmatic rocks in the region, or their volcanic equivalents. A possible source is the $2797 \pm 2$ Ma Rooibokvlei Granodiorite exposed in the Makoppa Dome $\sim 200 \mathrm{~km}$ north of Kusasalethu Mine (Age no. 7 in Fig. 2, reviewed by Anhaeusser, 2019).

This assumes that the provenance lay to the north of the present VCR occurrences, to the west is the $2791 \pm 8$ Ma Mosita Adamellite (Age no. 1 in Fig. 2).

Kositcin et al. (2004) also dated a few xenotime grains in the VCR, but got different ages within the same grains, which might reflect detrital, diagenetic or hydrothermal events.

\subsection{Sediment transport by water or ice?}

Most recent authors invoke a mainly fluvial transport mode for the Witwatersrand and VCR sedimentary rocks. (e.g. Frimmel, 2019; Kositcin and Krapež, 2004). However, there is evidence of glaciation on the Kaapvaal Craton during that time interval, very well-documented in the 2.94-2.87 Ga Mozaan Group in Kwazulu-Natal by Young et al. (1998) and correlated with the Witwatersrand Supergroup by Beukes and Cairncross (1991). Most of the gold reefs, including the VCR, lie unconformably on diamictites, striated pebbles were found associated with the Government and Coronation reefs (Rogers, 1922, CamdenSmith, 1980, Tankard et al., 1982), subglacial folding and varved shales are also recorded (Wiebols, 1955, McCarthy 2020). Literature evidence for glaciation in at least four reefs of the upper and lower (now West Rand and Central Rand Groups) Witwatersrand Supergroup was reviewed by Harland (1981). Recurring glacial ice sheets could account for the regional extent of the gold reefs and the long transport distances of detrital material suggested in the following section. 
The extensive weathering documented by Nwaila et al. (2017) in many Witwatersrand Supergroup shales could be ascribed to a warm climate, negating a glacial hypothesis. However, the likelihood of acidic conditions in rain and groundwater, enhanced by sulphur-rich volcanism, could also account for the high weathering and alteration indices which they reported. The action of acidic water on freshly ground glacial material could have enabled the dissolution and mobility of gold, which enhanced the grade of gold reefs, as proposed by Horscroft et al. (2012) and Heinrich, (2015).

\subsection{How much younger could the VCR be?}

There are a few known felsic magmatic rocks younger than $2900 \mathrm{Ma}$, which could have supplied zircon to the VCR after $2900 \mathrm{Ma}$, with localities numbered in Fig. 2 and detailed in supplementary Table A1. The VCR is interbedded with and was covered by Klipriviersberg Group mafic lavas. The $2714 \pm 16 \mathrm{Ma}$ ion probe U-Pb date of Armstrong et al. (1991, Table 1) for zircon from Klipriviersberg basalt is probably too young, as reviewed by Gumsley et al. (2020). Two mafic sills in the Witwatersrand Supergroup, which they dated at $2787 \pm 2 \mathrm{Ma}$ and 2789 $\pm 4 \mathrm{Ma}$ on baddeleyite (Table 1 ), are plausible feeders to the Klipriviersberg mafic lavas and do correspond geochemically. If these ages do represent Klipriviersberg volcanism, the youngest VCR detrital zircons could also represent that event, although felsic lavas have not been recorded in the Klipriviersberg Group. However, in our opinion the sillsare not unequivocally Klipriviersberg correlates.

Apart from the 2797 Ma Rooibokvlei Granodiorite and $2791 \mathrm{Ma}$ Mosita Adamellite referred to above, which are coeval with the $2799 \pm$ 9 Ma youngest VCR zircon grains, several zircon-bearing rock units which occur in the same areas (nos. 2 and 7 in Fig. 2), are significantly younger than that and may post-date the VCR. West of Amalia (No. 2 in Fig. 2), about $130 \mathrm{~km}$ from the nearest known VCR occurrence, four granitoids are dated at $2882 \pm 7$, to $2854 \pm 7 \mathrm{Ma}$ (Cornell et al., 2011). The $2785 \pm 2$ Ma Kanye Formation felsic lavas (Moore et al., 1993), and slightly younger $2781 \pm 5 \mathrm{Ma}$ Gaborone Granite (Walraven et al., 1996) crop out some $250 \mathrm{~km}$ north of the nearest VCR occurence (no. 5 in Fig. 2). If these rock units do post-date the VCR, they are time-correlates of the Ventersdorp Supergroup, as proposed by Gumsley et al. (2020) and discussed below.

\subsection{Constraints on age correlations of the Ventersdorp Supergroup with other units}

The time period in which the Ventersdorp Supergroup formed is now constrained between $2799 \pm 9 \mathrm{Ma}$, the maximum age of the VCR, and $2642 \pm 4 \mathrm{Ma}$, the age of volcanic rocks in the Vryburg Formation at the base of the Transvaal Supergroup (Walraven and Martini, 1995), which unconformably overlies the Ventersdorp rocks. In our opinion, the only reliable age for supracrustal rocks of the Ventersdorp Supergroup sensu stricto is $2720 \pm 2 \mathrm{Ma}$ for four samples of the Makwassie Formation in the Platberg Group, according to Cornell et al. (2017). Some other precise dates have been published on rocks which crop out outside the main repository and may be Ventersdorp correlates (reviewed by Gumsley et al., 2020).

Cornell et al. (2017) reported a $2874 \pm 16$ Ma zircon date from a sample ascribed to the Makwassie Formation at Kimberley. This date is unlikely to represent volcanism of the Ventersdorp Supergroup, because it is older than the VCR. Either that sample is coeval with the Witwatersrand Supergroup (detrital zircon grains $2872 \pm 12 \mathrm{Ma}$ and xenotime $2820 \pm 5 \mathrm{Ma}$ ), or more likely, the zircon grains dated were xenocrysts, supported by one grain in that sample dated at $2711 \pm 16 \mathrm{Ma}$.

The two zircon dates of $2781 \pm 5 \mathrm{Ma}$ and $2746 \pm 9 \mathrm{Ma}$, reported by Cornell et al. (2017) for the Goedgenoeg Formation at Kimberley and Wolmaransstad respectively, are within the possible age range for the Goedgenoeg Formation, although they might both be xenocrystic dates. They are unlikely to both be extrusion ages, because a minimum 21 million year duration of Goedgenoeg volcanism is considered to be unrealistic.

The Kanye Formation in eastern Botswana, which was dated at 2785 \pm 2 Ma by Moore et al. (1993), could be a time correlative of the Klipriviersberg Group in the lower Ventersdorp Supergroup, as suggested by Gumsley et al. (2020). However, its felsic composition is at odds with the komatiitic to basaltic composition of the Klipriviersberg Group.

The chronostratigraphic framework for the Ventersdorp Supergroup proposed by Gumsley et al. (2020) comprising a 2791-2779 Klipriviersberg LIP, a 2754-2709 Platberg volcanic province and a 2709-2683 Allanridge LIP does fit the time constraints for the Ventersdorp Supergroup. However, it is based largely on precise U-Pb baddeleyite dates on mafic rocks from sills which intrude the Witwatersrand and Pongola Supergroups, the Amsterdam Formation (which might be a Makwassie correlate) and older gneisses. In particular the Klipriviersberg LIP is based on two dated sills which are thought to represent feeders to the asyet undated Klipriviersberg lavas. None of these intrusive rocks are directly linked to volcanic strata of the Ventersdorp repository. A significant group of 2730-2701 Ma granitoids and two mafic dykes within the region up to $400 \mathrm{~km}$ east of the Ventersdorp basin are clearly time correlates of the Makwassie Formation, justifying the proposed Platberg volcanic province. In our opinion, the older and younger limits of Ventersdorp volcanism and the validity of the LIPs are still a matter for discussion.

\section{Conclusions}

The youngest group of six of 80 detrital zircon grains we dated in the Ventersdorp Contact Reef (VCR), from the base of the Ventersdorp Supergroup, are reliably dated at $2799 \pm 9$ Ma by laser ablation ICPMS. Thus the VCR was deposited after $2808 \mathrm{Ma}$ and before $2720 \pm 2 \mathrm{Ma}$, the age of the Makwassie Formation in the Platberg Group of the Ventersdorp Supergroup.

Zircon in the VCR probably originated largely as erosion products of the underlying Witwatersrand Supergroup. The VCR age histograms most closely resemble those of the Krugersdorp Formation, which is in the middle of the Central Rand Group, whereas histograms from units above that are less similar. This reflects the large erosional unconformity between the Witwatersrand Supergroup and the VCR, which in places cuts out most of the Central Rand Group.

The youngest $2799 \pm 9$ Ma zircon grains found in the VCR do not have known age-equivalents in the Witwatersrand Supergroup and may have been derived directly from magmatic rocks such as the $2797 \pm 2$ Ma Rooibokvlei Granodiorite or volcanic rocks, transported into the VCR repository by fluvial and possibly also by glacial processes.

Zircon grains from conglomerate samples from the VCR predominantly yield concordant $\mathrm{U}-\mathrm{Pb}$ ages. However about $15 \%$ of our data was discordant and conformed to the recent lead loss model, so that ${ }^{207} \mathrm{~Pb} /{ }^{206} \mathrm{~Pb}$ ages are not affected by discordance. Another $5 \%$ of the data showed complex Mesoproterozoic lead loss and those data points all have higher $\mathrm{Th}(>170 \mathrm{ppm})$ and generally higher $\mathrm{U}$ than the other points. This means that discordant data has to be carefully evaluated by analysing several points in each grain, as in this case $10 \%$ discordance due to lead loss at $\sim 1000$ Ma may lead to ages about 150 Ma too young.

The two large igneous provinces dated between 2791 and $2683 \mathrm{Ma}$, which have been proposed, based on the dating of mafic dykes outside the Ventersdorp repository, do fit the time constraints and might be related to Ventersdorp stratigraphy. However only the proposed 2754-2709 Ma Platberg volcanic province is coeval with reliably dated Platberg Group volcanic rocks of the Ventersdorp Supergroup sensu stricto. The validity of the other proposed LIPs and correlations is still under discussion.

\section{Declaration of Competing Interest}

The authors declare that they have no known competing financial 
interests or personal relationships that could have appeared to influence the work reported in this paper.

\section{Acknowledgements}

We thank the University of the Free State and the University of Gothenburg for financial and logistical support. The VCR samples were kindly supplied by Mr Johann Ackermann of Harmony Gold Mining Co. Ltd. The manuscript was substantially improved following reviews by Hartwig Frimmel, Chris Heinrich and Sharad Master. The COVID-19 virus kept us off the streets and our noses to the grindstone during this work.

\section{Appendix A. Supplementary data}

Supplementary data to this article can be found online at https://doi. org/10.1016/j.precamres.2021.106131.

\section{References}

Altermann, W., Lenhardt, N., 2012. The volcano-sedimentary succession of the Archean Sodium Group, Ventersdorp Supergroup, South Africa: volcanology, facies and geochemistry. Precambr. Res. 214-215, 60-81.

Andersen, T., Andersson, U.B., Graham, S., Åberg, G., Simonsen, S.L., 2009. Granitic magmatism by melting of juvenile continental crust: new constraints on the source of Palaeoproterozoic granitoids in Fennoscandia from Hf isotopes in zircon. J. Geol. Soc., London 166, 233-248.

Anhaeusser, C.R. 2019. Palaeo-, Meso- Neoarchaean Granite-Greenstone Basement Geology and Related Rocks of the Central and Western Kaapvaal Craton, South Africa. in Kröner, A., The Archaean Geology of the Kaapvaal Craton, Southern Africa. Springer, 312pp.

Armstrong, R.A., 1987. Geochronological studies on Archaean and Proterozoic formations of the foreland of the Namaqualand Front and possible correlates on the Kaapvaal craton. Ph.D. thesis unpublished. University of Witwatersrand, Johannesburg, p. 274.

Armstrong, R.A., Compston, W., Retief, E.A., Williams, I.S., Welke, H.J., 1991. Zircon ion microprobe studies bearing on the age and evolution of the Witwatersrand triad. Precambr. Res. 53, 243-266.

Barton, E.S., Compston, W., Williams, I.S., Bristow, J.W., Hallbauer, D.K., Smith, C.B., 1989. Provenance ages for the Witwatersrand Supergroup and the Ventersdorp Contact Reef: constraints from ion microprobe U-Pb ages of detrital zircons. Econ. Geol. 84, 2012-2019.

Barton, E.S., Compston, W., Williams, I.S., Bristow, J.W., Hallbauer, D.K., Smith, C.B., 1990. Provenance ages for the Witwatersrand Supergroup and the Ventersdorp contact reef; constraints from ion microprobe U-Pb ages of detrital zircons; reply. Econ. Geol. 85, 1951-1952.

Baughman, J.S., Flowers, R.M., 2020. Mesoproterozoic burial of the Kaapvaal craton, southern Africa during Rodinia supercontinent assembly from (U-Th)/He thermochronology. Earth Planet. Sci. Lett. 531, 115930.

Beukes, N.J., Cairncross, B., 1991. A lithostratigraphic-sedimentological reference profile for the Late Archaean Mozaan Group, Pongola Sequence: application to sequence stratigraphy and correlation with the Witwatersrand Supergroup. S. Afr. J. Geol. 94 44-69.

Camden-Smith, P.M., 1980. The sedimentology, geochemistry and diagenesis of West Rand Group sediments in the Heidelberg area, Transvaal. MSc thesis, unpublished, University of Cape Town, 96 pp.

Cornell, D.H., van Schijndel, V., Ingolfsson, I., Scherstén, A., Karlsson, L., Wojtyla, J., Karlsson, K., 2011. Evidence from Dwyka tillite cobbles of Archean basement beneath the Kalahari sands of southern Africa. Lithos 125, 482-502.

Cornell H, D., 1978. Petrologic Studies at T'Kuip: Evidence for metamorphism and metasomatic alteration of volcanic formations beneath the Transvaal volcanosedimentary pile. Trans. geol. Soc. S. Afr. 81, 261-270.

Cornell, D.H., Andersen, T., Corfu, F., Frei, D., Zack, T., van Schijndel, V., 2016. Th-U-Pb zircon geochronology of the Palaeoproterozoic Hartley Formation porphyry by six methods, with age uncertainty approaching 1 Ma. S. Afr. J. Geol. 119, 473-494.

Cornell, D.H., Meintjies, P.G., van der Westhuizen, W.A., Frei, D., 2017. Microbeam U-Pb zircon dating of the Makwassie and Goedgenoeg Formations in the Ventersdorp Supergroup of South Africa. S. Afr. J. Geol. 120, 525-540. https://doi.org/ 10.25131/gssajg.120.4.525.

Cornell, D.H., Minnaar, H., Frei, D., Kristoffersen, M., 2018. Precise microbeam dating defines three Archaean granitoid suites at the southwestern margin of the Kaapvaal Craton. Precambr. Res. 304, 21-38.

Chunnett, I.E., 1994. The Ventersdorp Contact Reef-A historical perspective. S. Afr. J. Geol. 97, 239-246.

De Kock, M.O., Beukes, N.J., Armstrong, R.A., 2012. New SHRIMP UPb zircon ages from the Hartswater Group, South Africa: implications for correlations of the Neoarchean Ventersdorp Supergroup on the Kaapvaal craton and with the Fortescue Group on the Pilbara craton. Precambr. Res. 204-205, 66-74.
Eglington, B.M., Armstrong, R.A., 2004. The Kaapvaal Craton and adjacent orogens, southern Africa: a geochronological database and overview of the geological development of the craton. S. Afr. J. Geol. 107, 13-32.

Frimmel, H.E., 2019. The Witwatersrand Basin and its gold deposits. In: Kröner, A., Hofmann, A. (Eds.), The Archaean Geology of the Kaapvaal Craton. Southern Africa, Springer Nature, pp. 255-275.

Grobler, D.F., Walraven, F., 1993. Geochronology of Gaborone Granite Complex extensions in the area north of Mafikeng, South Africa. Chem. Geol. 105, 319-337.

Gumsley, A., Stamsnijder, J., Larsson, E., Söderlund, U., Naeraa, T., de Kock, M., Sałacińska, A., Gaweda, A., Humbert, F., Ernst, R.E., 2020. Neoarchean large igneous provinces on the Kaapvaal Craton in southern Africa re-define the formation of the Ventersdorp Supergroup and its temporal equivalents. Geol. Soc. Am. Bull. 132, 1829-1844. https://doi.org/10.1130/B35237.1.

Hall, R.C.B., Els, B.G., Mayer, J.J., 1997. The Ventersdorp Contact Reef: final phase of the Witwatersrand Basin, independent formation, or precursor to the Ventersdorp Supergroup? S. Afr. J. Geol. 100, 213-222.

Harland, W.B., 1981. The Late Archaean (?) Witwatersrand conglomerates, South Africa. Chapter A32 in Hambrey, M.J., Harland, W.B. (editors), 1981. Earth's prePleistocene glacial record. Cambridge University Press.

Heinrich, C.A., 2015. Witwatersrand gold deposits formed by volcanic rain, anoxic rivers and Archaean life. Nat. Geosci. 8, 206-209.

Henckel, J., Schweizer, J.K., 1994. Geochemical and mineralogical characteristics of a portion of the Ventersdorp Contact Reef at Elandsrand Gold Mine. S. Afr. J. Geol. 97, 332-338.

Horscroft, F.D.M., Mossman, D.J., Reimer, T.O., Hennigh, Q., 2012. Witwatersrand metallogenesis: the case for (modified) syngenesis. Soc. Sediment. Geol. Special Publication 11, 75-95.

Koglin, N., Zeh, A., Frimmel, H.E., Gerdes, A., 2010. New constraints on the auriferous Witwatersrand sediment provenance from combined detrital zircon U-Pb and Lu-Hf isotope data for the Eldorado Reef (Central Rand Group, South Africa). Precambr. Res. 183, 817-824.

Kositcin, N., Krapež, B., 2004. Relationship between detrital zircon age-spectra and the tectonic evolution of the Late Archaean Witwatersrand Basin, South Africa. Precambr. Res. 129, 141-168.

Kositcin, N., McNaughton, N.J., Griffin, B.J., Fletcher, I.R., David, I., Groves, D.I., Rasmussen, B., 2003. Textural and geochemical discrimination between xenotime of different origin in the Archaean Witwatersrand Basin, South Africa. Geochim. Cosmochim. Acta 67, 709-731.

Manzi, S.D., Hein, A.A., King, N., Durrheim, R.J., 2013. Neoarchaean tectonic history of the Witwatersrand Basin and Ventersdorp Supergroup: new constraints from highresolution 3D seismic reflection data. Tectonophysics 590, 94-105.

McCarthy, T.S., 1994. The tectono-sedimentary evolution of the Witwatersrand Basin with special reference to its influence on the occurrence and character of the Ventersdorp Contact Reef. A review. S. Afr. J. Geol. 97, 247-259.

McCarthy, T.S., 2020. Wits Gold - New thoughts on an old problem. Zoom talk, Geological Society of South Africa, Thursday 3 September. ttps://www.youtube. com/watch? $\mathrm{v}=\mathrm{WxVfbQ1P8MI}$.

Moore, M., Davis, D.W., Robb, L.J., Jackson, M.C., Grobler, D.F., 1993. Archaean rapakivi granite - anorthosite - rhyolite complex in the Witwatersrand Basin hinterland, southern Africa. Geology 21, 1031-1034.

Nwaila, G., Frimmel, H.E., Minter, W.E.L., 2017. Provenance and geochemical variations in shales of the mesoarchean witwatersrand supergroup. J. Geol. 125, 399-422. https://doi.org/10.1086/692329.

Poujol, M., Kiefer, R., Robb, L.J., Anhaeusser, C.R., Armstrong, R.A., 2005. New U-Pb data on zircons from the Amalia greenstone belt Southern Africa: insights into the Neoarchean evolution of the Kaapvaal Craton. S. Afr. J. Geol. 108, 317-332.

Rogers, A.W., 1922. The geology of the country around Heidelberg. Explanation of the geological map. Geological Survey, Pretoria, 84pp.

Schweitzer, J., Kröner, A., 1985. Geochemistry and petrogenesis of early Proterozoic intracratonic volcanic rocks of the Ventersdorp Supergroup, South Africa. Chem. Geol. 51, 265-288.

Tankard, A.J., Jackson, M., Eriksson, K.A., Hobday, D.K., Hunter, D.R., Minter, W.E.L., 1982. Crustal Evolution of Southern Africa, 3.8 Billion Years of Earth History. Springer-Verlag, New York, p. 523.

Van der Westhuizen, W.A., de Bruiyn, H., Meintjes, P.G., 2006. The Ventersdorp Supergroup. In: Johnson, M.R., Anhaeusser, C.R., Thomas, R.J. (Eds.), 2006. The Geological Society of South Africa, Johannesburg/Council for Geoscience, Pretoria, The Geology of South Africa, pp. 187-208.

Walraven, F., Martini, J., 1995. Zircon Pb-evaporation age determinations of the Oak Tree Formation, Chuniespoort Group, Transvaal Sequence: implications for the Transvaal-Griqualand West basin correlations. S. Afr. J. Geol. 98, 58-67.

Walraven, F., Grobler, D.F., Key, R.M., 1996. Age equivalence of the Plantation Porphyry and the Kanye volcanic formation, southeastern Botswana. S. Afr. J. Geol. 99, 23-31.

J.H. Wiebols A suggested glacial origin for the Witwatersrand conglomerates. Transactions of the Geological Society of South Africa 58, 367-382.

Wingate, M.T.D., 1998. A palaeomagnetic test of the Kaapvaal-Pilbara Vaalbara connection at 2.78 Ga S. Afr. J. Geol. 1011955257274.

Young, G., Brunn, V., Gold, D., Minter, W., 1998. Earth's oldest reported glaciation: Physical and chemical evidence from the Archean Mozaan Group ( $2.9 \mathrm{Ga})$ of South Africa. J. Geol. 106, 523-538. https://doi.org/10.1086/516039.

Zhao, B., Clauer, N., Robb, L.J., Zwingmann, H., Toulkeridis, T., Meyer, F.M., 1999. K-Ar dating of white micas from the Ventersdorp Contact Reef. Mineral. Petrol. 66, 149-170. 